\title{
GLOBALISASI DAN TANTANGAN DAKWAH
}

\author{
Abdul Hamid \\ Universitas Islam As-Syafi'iyah \\ Jln. Raya Jatiwaringin No. 12 Pondok Gede Jakarta Timur 13077 \\ Email: salamku82@yahoo.com
}

\begin{abstract}
Globalization and the Challenge of Dakwah. A comprehensive review of the meaning of globalization, the history of globalization, the forms of globalization, and the extent of globalization's influence on the Islamic world. The emergence of this era of globalization is a challenge in the world of da'wah, all humans will definitely experience it. To pass through this postmodernism, concrete and systematic steps are needed to serve as a life reference which is expected to restore man to the purpose and purpose he created, by utilizing the progress of the world of globalization. Surely there will be obstacles and obstacles that must be faced, because not all the progress that exist in this era of globalization is accepted by the teachings of Islam. Therefore, in addition to utilizing technological developments, dawah is also expected as a counterweight to the consequences of these technological developments.
\end{abstract}

Keywords: Globalization, Da'wah, Islam

\begin{abstract}
Abstrak: Globalisasi dan Tantangan Dakwah. Kajian komprehensif tentang makna globalisasi, sejarah globalisasi, bentuk-bentuk globalisasi, serta sampai di mana besarnya pengaruh globalisasi terhadap dunia Islam. Munculnya era globalisasi ini merupakan tantangan dalam dunia dakwah, mau atau tidak semua manusia akan mengalaminya. untuk mengarungi postmodernism ini, dibutuhkan langkah-langkah yang konkrit dan sistematik untuk dijadikan sebagai acuan hidup yang diharapkan mampu mengembalikan manusia kepada maksud dan tujuan ia diciptakan, dengan memanfaatkan kemajuan dunia globalisasi. Tentunya pasti akan ada rintangan-rintangan serta hambatan yang harus dihadapi, karena tidak semua kemajuan yang ada di era globalisasi ini diterima oleh ajaran Islam. Oleh sebab itu, selain memanfaatkan perkembangan teknologi itu sendiri dakwah juga diharapkan sebagai penyeimbang terhadap akibat dari perkembangan teknologi itu sendiri.
\end{abstract}

Kata kunci: Globalisasi,Dakwah, Islam 


\section{Pendahuluan}

Banyak sejarawan yang menyebut globalisasi ${ }^{1}$ sebagai fenomena di abad ke-20 ini yang dihubungkan dengan bangkitnya ekonomi internasional. ${ }^{2}$ Padahal interaksi dan globalisasi dalam hubungan antarbangsa di dunia telah ada sejak berabad-abad yang lalu. Bila ditelusuri, benih-benih globalisasi telah tumbuh ketika manusia mulai mengenal perdagangan antarnegeri sekitar abad ke-1-7 M. ${ }^{3}$ Saat itu, para pedagang Muslim Arab, Persia, dan India, Tiongkok mulai menelusuri negeri lain baik melalui jalan darat maupun jalan laut untuk berdagang. ${ }^{4}$

Fase selanjutnya ditandai dengan dominasi perdagangan kaum muslim di Asia dan Afrika. Kaum muslim membentuk jaringan perdagangan yang antara lain meliputi Jepang, Tiongkok, Vietnam, Indonesia, Malaka, India, Persia, pantai Afrika Timur, Laut Tengah, Venesia, dan Genoa. Di samping membentuk jaringan dagang, kaum pedagang muslim juga menyebarkan nilai-nilai agamanya, nama-nama, abjad, arsitek, nilai sosial dan budaya Arab ke warga dunia. ${ }^{5}$

Fase selanjutnya terus berjalan dan mendapat momentumnya ketika perang dingin berakhir dan komunisme di dunia runtuh. Runtuhnya komunisme seakan memberi pembenaran bahwa kapitalisme adalah jalan terbaik dalam mewujudkan kesejahteraan dunia. Implikasinya, negara negara di dunia mulai menyediakan diri sebagai pasar yang bebas. Hal ini didukung pula dengan perkembangan teknologi komunikasi dan transportasi. Alhasil, sekat-sekat antar negara pun mulai kabur. ${ }^{6}$

${ }^{1}$ Menurut Qaradhawi, Globalisasi adalah penjajahan lama yang tampil dalam busana dan nama baru. Lihat Qaradhawi, Islam dan Globalisasi Dunia, (Jakarta Timur, CV. Pustaka Al-Kautsar: 2001), cet ke-1, h. 31. Menurutnya, globalisasi memiliki makna yang sangat berdekatan dengan AlAlamiyah yang di bawah oleh Islam. Namun ada perbedaan yang yang cukup mendasar antara makna yang Alamiyah yang dibawah oleh Islam dengan yang diserukan oleh barat pada umunya, khususnya Amerika. Alamiyah yang dibawah oleh Islam datang untuk menghormati umat manusia (QS. Al-Isra': 70). Ibid.,h. 25. Berbeda dengan globalisasi yang di kampanyekan oleh dunia barat yang merupakan keharusan pengawasan dibidang politik, ekonomi, budaya, dan social. Ibid., h. 27. Menurut Qodri Azizy, bahwa era globalisasi adalah terjadinya pertemuan dan gesekan nilai-nilai budaya dan agama di seluruh dunia yang memanfaatkan jasa komunikasi, transformasi, dan informasi hasil modernisasi tersebut. Lihat A. Qodri Azizy, Melawan Globalisasi, (Yogyakarta: Pustaka Pelajar, 2004), h. 20

2 A. Qodri Azizy, Melawan Globalisasi, (Yogyakarta: Pustaka Pelajar, 2004), h. 1

${ }^{3}$ Badri Yatim, Sejarah Peradaban Islam, (Jakarta: Raja grafindo Persada, 2008), h. 191

${ }^{4}$ Badri Yatim, Sejarah Peradaban Islam, h 191

${ }^{5}$ Badri Yatim, Sejarah Peradaban Islam, h. 175-176

${ }^{6}$ Badri Yatim, Sejarah Peradaban Islam, h. 169 
Hal ini, tentunya akan membawa pengaruh yang sangat signifikan terhadap orientasi dakwah. Untuk mendukung hal tersebut kajiankajian syariat perlu disejajarkan dengan kajian-kajian non syariat yang merujuk kapada perkembangan ilmu pengetahuan dan teknologi, karena perkembangan teknologi terutama perkembangan teknologi komunikasi tidak hanya mempengaruhi satu bidang kehidupan masyarakat melainkan hampir mempengaruhi seluruh bidang kehidupan. Oleh sebab itu, selain memanfaatkan perkembangan teknologi itu sendiri dakwah juga diharapkan sebagai penyeimbang terhadap akibat dari perkembangan teknologi itu sendiri. Keragaman hidup duniawi, serbuan berbagai nilai yang bersifat hedonisme dan konsumerisme dakwah dapat memberikan arahan dan bimbingan agar umat tidak mengalami disorientasi dalam rumah peradaban dunia yang penuh dinamika. ${ }^{7}$

Dengan demikian, menurut penulis perlu diadakan kajian kembali yang lebih komprehensif tentang makna globalisasi, sejarah globalisasi, bentuk-bentuk globalisasi, serta sampai di mana besarnya pengaruh globalisasi terhadap dunia Islam. Munculnya era globalisasi ini merupakan tantangan dalam dunia dakwah, mau atau tidak semua manusia akan mengalaminya. Nah, untuk mengarungi postmodernism ini, dibutuhkan langkah-langkah yang konkrit dan sistematik untuk dijadikan sebagai acuan hidup yang diharapkan mampu mengembalikan manusia kepada maksud dan tujuan ia diciptakan, dengan memanfaatkan kemajuan dunia globalisasi. Tentunya pasti akan ada rintangan-rintangan serta hambatan yang harus dihadapi, karena tidak semua kemajuan yang ada di era globalisasi ini diterima oleh ajaran Islam. Maka untuk lebih spesifik, perlulah kiranya kita memahami tantangan-tantangan tersebut.

Al-Aulamah (globalisasi) ${ }^{8}$ merupakan istilah yang diperhalus dari penjajahan baru. Globalisasi dalam bentuknya yang paling jelas dewasa ini mempunyai maksud westernisasi dunia atau dengan ungkapan lain: Amerikanisasi dunia. Istilah yang sangat gencar dikampanyekan ini merupakan keharusan pengawasan dalam bidang politik, ekonomi, kebudayaan dan sosial yang di lakukan oleh Amerika terhadap dunia,

${ }^{7}$ Fathul Wahid, e-Dakwah: Dakwah Melalui Internet, (Yogyakarta: Gava Media,, 2004), h. 25

${ }^{8}$ Qaradhawi membagi globalisasi dalam empat bentuk, yaitu Globalisasi Politik, Globalisasi Ekonomi, Globalisasi Kebudayaan, Globalisasi Agama, Lihat Qaradhawi, Islam dan Globalisasi Dunia, (Jakarta: Pustaka al-Kautsar, 2001), Cet ke-1, h. 35-89 
khususnya dunia Islam. Maka dalam bab ini akan dibahas tentang globalisasi poltik, globalisasi ekonomi, globalisasi kebudayaan, globalisasi agama berikut tantangan-tantangannya dalam dunia dakwah.

\section{Globalisasi Politik}

Di tinjau dari lingkungan nasional, kondisi persatuan dan kesatuan bangsa dapat dikatakana mengalamai perubahan yang sangat signifikan. Globalisasi politik ini dapat mengakibatkan ancaman dalam bentuk subversi asing yang ingin memaksakan kehendak politknya yang bertentangan dengan ideologi setiap bangsa. Hal ini akan memicu loyalitas masyarakat terhadap bangsa menjadi berkurang. ${ }^{9}$

Tujuan dari pada globalisasi politik ini sebenarnya ingin menjadikan dunia dalam satu kekuasaan yang akan dikendalikan oleh Negara yang memiliki kekuatan super power, tentun saja dalam hal ini adalah Amerika. Adanya kekuatan super power ini, semua negara-negara dipaksa untuk ikut dalam semua peraturan yang ditentukannya. Secara signifikan globalisasi sebenarnya telah melemahkan negara. Kedaulatan negara menjadi kabur. Karenanya kapasitas negara sebagai aktor utama dalam hubungan internasional dan sebagai kekuatan domestik untuk menyejahterakan rakyat semakin dipertanyakan. Di tingkat internasional secara substansional, negara melemah karena pergesaran pertanyaan dari: Apa itu negara?, dan menjadi siapa itu negara? Hal ini terutama disebabkan oleh fakta bahwa negara dalam politik domestik dan internasional lebih banyak mewakili dan memperjuangakn kepentingan pemegang otoritas (keluarga, kelompok dan sebagainya yang secara kasat mata termanifestasi dipublik domestik dan dunia) dari pada kepentingan seluruh warga negara yang ada diwilayahnya yang menjadi sebab adanya negara tersebut. ${ }^{10}$

Di samping itu pemerintah yang memegang otoritas negara sering kali takluk kepada kepentingan bisnis transnasional dan domestik serta tunduk kepada massa yang mengendalikan poltik, yang memiliki kapasitas untuk mobilisasi kekerasan dan kejahatan. Munculnya kekuatan-kekuatan

\footnotetext{
${ }^{9}$ Liasta Ginting, makalah ancaman globalisasi dan regionalisasi, Universitas Sumatra Utara Medan, 2005, h. 5

${ }^{10}$ Peper pengantar untuk seminar, Lumpuhnya Sistem Keadilan: Tantangan Penegakkan Hakhak Azazi Manusia dan Peran Advokat Untuk Kepentingan Publik, yang di selenggarakan oeh Elsam Sawith Wach, HUMA, 3-5 Aug 2010, Jakarta.
} 
non-pemerintah yang memiliki jaringan mulai dari tingkat lokal sampai tingkat global yang juga mempengaruhi kebijakan dan tata kelola pemerintah mulai dari sub-nasional, nasional, regional sampai kepada global. Organisasi-organisasi ini juga sering terlibat dalam diplomasi untuk memperjuangkan kepentingan masyarakat dan kepentingan tertentu. Bahkan mereka bergandengan tangan dengan aktor-aktor tertentu dalam kanca diplomasi internasional. Karena itu pemisahan antara aktor negara dan non-negara dalam era globalisasi mengaburkan batas tertorial dan batas pengaruh suatu bangsa. ${ }^{11}$

Perdebatan yang paling besar dalam dunia politik adalah berkenaan dengan nasib negara atau bangsa modern, beberapa pertanyaan yang perlu diajukan adalah: (1) Sebab-sebab politik apakah yang mendorong arus massif capital, uang, dan teknologi melintasi batas-batas territorial? (2) Apakah arus ini merupakan tantangan yang serius terhadap keberdayaan nationstate? (3) Bagaimanakah dampak munculnya oraganisasi-organisasi intergovernmental terhadap konsep kedaulatan Negara dan bagaimana prospek global governance?

Dalam merumuskan jawaban di atas menurut Subhihar dan Indra $\mathrm{K},{ }^{12}$ ada empat pendapat yang berbeda-beda yakni;

Pertama, mereka menganggap bahwa globalisasi merupakan proses yang secara instrinsik berkaitan dengan ekspansi pasar. Secara lebih khusus, kemajuan pesat dalam teknologi komputer dan sistem komunikasi seperti jaringan lintas dunia di pandang sebagai kekuatan utama yang bertanggungjawab atas terciptanya pasar global. Menurut pandangan ini politik nyaris tanpa daya di hadapan truk besar teknoekonomi yang tak terhalau yang akan melabrak upaya pemerintah mengintroduksi kembali kebijakan dan aturan-aturan yang restriktif. Pembagian wilayah tidak lagi relevan dengan masyarakat, Negara tidak lagi mampu menderminasi arah kehidupan social dalam batas-batas wilayah mereka. Negara dalam pendisplinan pasar global semakin kerdil kemampuannya dalam mengontrol nilai tukar dan memproteksi mata uangnya. ${ }^{13}$

\footnotetext{
${ }^{11}$ Peper pengantar untuk seminar, Lumpuhnya Sistem Keadilan: Tantangan Penegakkan Hakhak Azazi Manusia dan Peran Advokat Untuk Kepentingan Publik,

12 Subhihar dan Indra Kesuma Nasution adalah Dosen FISIP-USU, dalam tulisannya yang berjudul Dinia Islam di Tengah Globalisasi, h. 36-37

${ }^{13}$ Subhihar dan Indra Kesuma Nasution, Dunia Islam di Tengah Globalisasi,h. 36-37
} 
Kedua, Menampik anggapan bahwa perubahan ekonomi berskala besar semata-semata terjadi dalam masyarakat sebagai sesuatu yang alamiah seperti misalnya gempa bumi. Melainkan mereka menyoroti peran sentarl politik khususnya mobiltas kekuasaan politik dalam menebarkan jaringanjaringan diseminasi globalisasi. Jika bentuk globalisasi ekonomi di tentukan oleh politik maka preferensi politik yang berbeda akan menghasilkan kondisi sosial yang berbeda pula. ${ }^{14}$

Ketiga, Glibalisasi adalah sebagai akibat dari perpaduan antara faktor politik dan teknologi. Pembiakan teknologi baru yang cepat dan tak dapat di elakkan merambah ke seluruh penjuruh dunia yang membuat modernisasi masyarakat dunia yang di bombing oleh teknologi menjadi sebuah takdir sejarah. Namun tidak ada Negara yang memiliki kekuatan hegemoni yang mewujudkan pasar bebas sejagat. Dunia akan runtuh tatkala keseimbangannya tidak lagi dapat di pertahankan. Karena itu, perang perdagangan akan membuat kerjasama inteernasional akan lebih sulit. ${ }^{15}$

Keempat, Ilmuwan politik seperti Held dan Falk dalam tulisantulisan mereka mengartikulasikan perlu adanya global governance sebagai konsekuensi logis proses globalisasi. Keduanya menggambarkan bahwa globalisasi telah mengikis pemerintah nasional. Held menawarkan munculnya bentuk demokrasi multi lapis yang bercita-cita pada cosmopolitan barat, pengaturan hukum internasional dan jaringan luas yang menghubungkan antara berbagai institusi kepemerintahan dan non kepemerintahan. ${ }^{16}$

Tantangan yang paling berat di lingkungan dakwah adalah karena seorang daii harus berhadapan dengan aktor utama yaitu pemerintah yang tidak menjalankan fungsinya untuk memenuhi kepentigan masyarakat atau rakyatnya karena pemerintah yang membuat undang-undang, kebijakan, perjanjian dengan Negara-negara lain atau lembaga-lembaga internasional. Masuknya informasi-informasi dari luar tanpa adanya penyaringan sehingga akan membahayakan martabat dan moral bangsa, masyarakat tidak merasa lagi memiliki Negara karena ia milik global. Seruan akan adanya kebebasan antara kaum pria dan wanita di kanca politk dunia makin menunjukan pamornya. Undang-undang Internasional yang di sebut globalisasi itu kembali memperlihatkan kekuatannya meiliter, hancurnya dunia Islam itu

\footnotetext{
${ }^{14}$ Subhihar dan Indra Kesuma Nasution, Dunia Islam di Tengah Globalisasi, h. 36-37

15 Subhihar dan Indra Kesuma Nasution, Dunia Islam di Tengah Globalisasi, h. 36-37

${ }^{16}$ Subhihar dan Indra Kesuma Nasution, Dunia Islam di Tengah Globalisasi, h. 36-37
} 
karena gencarnya Negara-negara barat untuk mangatur peraturan global dunia sehingga mereka dengan leluasanya menyerang dunia Islam kapan saja mereka mau bahkan mereka juga mampu mambasmi gerakan-gerakan Islam yang berada di dunia Islam. Ini menunjukan bahwa Islam sudah tidak memiliki nyali lagi di mata dunia. Penangkapan para aktifis dakwah Islam kian berani di mana-mana dengan dalih bahwa mereka adalah teroris, pada hal semua itu tidak memiliki bukti yang kuat, bahka kalau di telusuri lebih konkrit ternyata merekalah yang berada di balik kejahatan yang berada di dunia Islam selama ini. ${ }^{17}$

\section{Globalisasi Ekonomi}

Globalisasi ekonomi menimbulkan masalah-masalah yang bersifat global pula. Masalah globalisasi dalam tatanan ekonomi nasional Indonesia dapat dilihat dari dua sudut pandang: dampak globalisasi terhadap kondisi internal dan dampak globalisasi terhadap kondisi eksternal. Bentuk dampak pada kedua sisi inipun dapat berupa dampak positif dan dampak negatif. ${ }^{18}$

Dalam hal dampaknya pada kondisi internal, globalisasi dapat mengubah pola perilaku pelaku ekonomi dalam proses produksi di satu pihak dan perubahan struktural ekonomi serta kebijakan ekonomi pemerintah di lain pihak. Perubahan dalam proses produksi antara lain dapat meliputi efisiensi dan intensifikasi penggunaan faktor produksi, bertambahnya frekuensi perdagangan dan investasi pada sektor-sektor yang dapat diperdagangkan (tradeable), serta berkembangnya industri nasional yang kompetitif. Sedangkan perubahan struktural yang mungkin terjadi dapat meliputi perubahan dalam sektor ekonomi dan orientasi sektor tradisional kepada sektor ekonomi modern. Perkembangan ini membawa implikasi pada perubahan kebijakan ekonomi mikro perusahaan, makro ekonomi, kebijakan pasar, dan lain-lain. ${ }^{19}$ 1, h. $35-38$

${ }^{17}$ Al-Qaradhawi, Islam dan Globalisasi Dunia, (Jakarta: Pustaka al-Kautsar, 2001), Cet. ke-

${ }^{18}$ Menurut A. Qodri Azizy Ada dua pengaruh psikologis yang di munculkan oleh AFTA (ASEAN Free Trade Agrement) atau perjanjian kawasan perdagangan bebas ASEAN ini, yaitu dampak yang bersifat positif dan dampak yang bersifat negatif. Uraian selengkapnya baca A. Qodri Azizy, Melawan Globalisasi, (Yogyakarta: Pustaka Pelajar, 2004), h. 59-60

${ }^{19}$ Ibid., Bandingkan dengan Qaradhawi, Islam dan Globalisasi Dunia, (Jakarta: Pustaka alKautsar: 2001), Cet ke-1, h. 39-54 
Perubahan pada kondisi eksternal, dapat meliputi perubahan dalam kebijakan perdagangan dan investasi internasional, sistem moneter internasional, dan hubungan ekonomi internasional lainnya. Perubahanperubahan yang terjadi ini selanjutnya tidak lagi dapat diidentifikasikan sebagai kegiatan nasional, melainkan sudah bersifat global. Selain dampak globalisasi pada aspek ekonomi, globalisasi dapat pula menimbulkan perubahan pada bidang non-ekonomi, seperti dalam sektor pendidikan, kesehatan, kependudukan, dan lingkungan hidup. ${ }^{20}$

Positif atau negatifnya dampak yang ditimbulkan dengan adanya perubahan-perubahan itu sangat tergantung pada kemampuan daya saing produk yang dihasilkan, kualitas sumber daya manusia, kemampuan adaptasi, dan kebijakan pemerintah. Apabila faktor-faktor ini dimiliki oleh suatu perekonomian, maka walaupun globalisasi dapat menghasilkan berbagai perubahan perekonomian suatu negara, globalisasi justru dapat memberikan keuntungan bagi perekonomian itu sendiri. ${ }^{21}$

Dampak globalisasi ekonomi cenderung akan menghasilkan kondisi eksternal negatif jika perekonomian tidak dapat bersaing dan tetap ifisien. Adanya eksternalitas negatif ini merupakan akibat dari ketidakmampuan pelaku ekonomi nasional dalam memperebutkan peluang pasar dan mengoptimalkan pemanfaatan sumber-sumber perekonomian nasional. Hal ini terutama karena kekuatan dan daya saing ekonomi nasional kita masih lemah. Kurangnya daya saing ini terutama disebabkan karena kelemahan implementasi kebijakan protektif pemerintah selama lebih dari tiga dekade. Seperti yang banyak kita ketahui, industri kita-terutama manufaktur-banyak yang memulai infant industry-nya diproses produksi hilir yang diproteksi oleh kebijakan pemerintah seperti perakitan mobil dan penguliran pipa misalnya. Sayangnya implementasi kebijakan protektif

${ }^{20}$ Uraian lengkapnya silahkan baca tulisan Bonnie Setiawan yang berjudul: At The End of Globalisation, We Are All Dead. Tulisan ini judulnya berbahasa inggris tapi urainnya dalam bahasa Indonesia. Beliau adalah Direktur Eksekutif di Institute for Global Justice (IGJ) di Jakarta (www.globaljust.org, igj@globaljust.org ), sebuah NGO yang melakukan advokasi isu-isu WTO dan Globalisasi.

${ }^{21}$ Uraian selengkapnya baca A. Qodri Azizy, Melawan Globalisasi, (Yogyakarta: Pustaka Pelajar, 2004), h. 55-69 dan bandingkan dengan uraian yang di paparkan oleh Subhihar dan Indra Kesuma Nasution Dosen FISIP-USU, dalam tulisannya yang berjudul Dunia Islam di Tengah Globalisasi, serta Peper pengantar untuk seminar, Lumpuhnya Sistem Keadilan: Tantangan Penegakkan Hak-hak Azazi Manusia dan Peran Advokat Untuk Kepentingan Publik, yang di selenggarakan oeh Elsam Sawith Wach, HUMA, 3-5 Aug 2010, Jakarta. 
tersebut tidak dibarengi dengan suatu kondisi yang dapat memaksa pelaku industri untuk menginvestasikan hasil keuntungannya ke proses produksi hulu. Para pelaku industri justru banyak yang menginvestasikan hasil keuntungan dari kebijakan protektif tersebut ke jenis industri lain yang juga diproses produksi hilir. Akibatnya sampai sekarang industri kita masih bergantung pada import resources untuk input produksinya; baik itu humanware, technoware, infoware, orgaware, maupun pendanaan. Industri kita hanya mampu membuat barang "made in Indonesia" tetapi bukan "made by Indonesians" karena 'ruh' teknologinya belum dikuasai penuh. ${ }^{22}$

Krisis multi dimensi yang masih berlanjut hingga saat ini, walaupun intensitasnya berkurang, dapat memperparah kerentanan ekonomi nasional. Proses pemulihan ekonomi kita relatif lamban dibandingkan negara-negara Asia lain seperti Thailand, Malaysia, dan Korea Selatan. Negara-negara ini secara umum telah pulih dari krisis yang dialaminya. Oleh karena itu, dalam keadaan ekonomi nasional yang semakin terintegrasikan dengan tatanan ekonomi dunia pada abad sekarang ini, kondisi yang diperlukan adalah kemampuan menyesuaikan diri dengan setiap perkembangan yang terjadi, dalam pengertian dapat memanfaatkan dengan baik peluang yang muncul dan menangkal dampak negatifnya. Langkah penyesuaian ini harus dilakukan dalam bentuk kebijaksanaan makro, sektoral, serta mikro yang adil dan merata. Selain itu diperlukan juga penyusunan rumusan skenario kebijakan ekonomi nasional agar eksternalitas negatif dari globalisasi dapat diminimalkan, bahkan mengubahnya menjadi peluang-peluang (opportunities). ${ }^{23}$

Maka globalisasi pada akhirnya akan menggilas perekonomian nasional karena ketatnya persaingan dengan pelaku ekonomi dari luar dihampir seluruh kegiatan ekonomi. Tergilasnya ekonomi dapat menimbulkan krisis ekonomi babak kedua yang akan menyebabkan semakin besarnya tingkat kemiskinan dan ketimpangan pendapatan masyarakat, tingginya tingkat pengangguran, kompetisi yang tidak sehat antar pelaku ekonomi, dan memperparah kerusakan lingkungan hidup. ${ }^{24}$

${ }^{22}$ A. Qodri Azizy, Melawan Globalisasi h. 55-69,

${ }^{23}$ Lebih lengkapnya baca tulisan Sity Daud. PhD, yang berjudul Globalisasi dan Negara Pembangunan, Pusat Pengajian Sejarah Politik dan strategi, Fakulti Sains Sosial dan Kemanusiaan Universitas Kebangsaan Malaysia, akademik 64 Januari 2004. Bandingkan dengan Bandingkan dengan Qaradhawi, Islam dan Globalisasi Dunia, (Jakarta: Pustaka al-Kautsar, 2001), Cet ke-1, h. $39-40$

${ }^{24}$ Qaradhawi, Islam dan Globalisasi Dunia, h.39-40 


\section{Globalisasi Kebudayaan}

Para budayawan melihat bahwa budaya pada awalnya suatu yang independensial bagi setiap bangsa, namun sejak kemajuan budaya terutama dibidang teknologi komunikasi, budaya tidak lagi bersifat kolektif, kini yang terjadi adalah munculnya hegemoni budaya, yang melahirkan satu bangsa dengan multi budaya. Lajunya kebudayaan material terutama dalam segi kebutuhan hidup, teknologi, barang atau perlengkapan terlebih sejak ditemukannya mikro prosesor pertama 1971 yang dibantu oleh penemuan PC pertama 1975 dan internet 1993 pilar-pilar budaya lokal semakin rapuh. Jauh sebelum itu tahun 1920 Angaya Jazz dengan rambut pendek kaum wanita saja sudah dapat merambah dunia. Apalagi dengan adanya instrumen seperti internet tahun 1997-an dapat dibayangkan kecepatan asimilasi dan akulturasi semakin meroket. ${ }^{25}$

Dari sudut sosiol seperti diungkap terdahulu, pengaruh industrialisasi juga telah menggeser asimilasi keluarga. Artinya nilai-nilai keluarga terkubur dengan nilai faktori dan pabrik, bagaimana jadinya jika setiap anggota keluarga bebas menerima informasi tanpa batas, tentu saja format keluarga menjadi berubah, panggilan, keharmonisasian, dan kehawatiran juga akan berubah. Di Amerika Serikat, karena kehawatiran akan apa yang ditemui anaknya di luar rumah para orang tua telah membudayakan home schooling atau sekolah dirumah-rumah sejak tahun $1999 .{ }^{26}$

Selanjutnya, globalisasi dalam bentuk yang alami akan meninggikan berbagai budaya dan nilai-nilainya. Dalam proses alami ini, setiap bangsa akan berusaha menyesuaikan budaya mereka dengan perkembangan baru sehingga mereka dapat melanjutkan kehidupan dan menghindari kehancuran. Tetapi dalam proses ini, negara-negara Dunia Ketiga harus memperkokoh dimensi budaya mereka dan memelihara struktur nilainilainya agar tidak dieliminasi oleh budaya asing. Dalam rangka ini, berbagai bangsa Dunia Ketiga haruslah mendapatkan informasi ilmiah yang bermanfaat dan menambah pengalaman mereka. ${ }^{27}$

${ }^{25}$ M. Tata Taufik, Dakwah Era Global, (kuningan: senin 27 Januari 2003, h. 92

${ }^{26}$ M. Tata Taufik, Dakwah Era Global, h.92

${ }^{27}$ Al-Qaradhawi mengatakan bahwa kebudayaan global adalah kebudayaan yang menyuruh kita menjadi budak yang tidak punya harga diri. Menjadi orang-orang yang patuh dan mau di setir oleh Israel-Amerika atau Amerika-Israel. Suatu sikap yang bertahun-tahun kita tolak dan kita anggap sebagai suatu sikap penghinatan dan kemungkaran bahkan sesuatu kekufuran yang nyata. Kebudayaan global adalah kebudayaan yang menyuruh kita agar kita mengakui eksistensi Israel 
Manusia harus berhadapan dengan seni yang digunakan untuk menjajah masyarakat dunia, padahal inilah bermulanya segala masalah. Dalam hal ini, dapat di ambil contoh yaitu industri perfilman Hollywood. Industri ini mengeluarkan 700 film dalam setahun dan mempunyai banyak sekali peminat di seluruh dunia sehingga secara praktis, film telah berubah menjadi sarana penjajahan Amerika. Namun, menurut doktor Bulkhari ${ }^{28}$, masalah ini tidak bisa dilihat hanya dari sudut seni saja. Dalam kasus ini, Barat atau khususnya AS, telah mengunakan seni sebagai alat untuk menyebarkan imperialismenya di dunia. Dalam pandangan peneliti Iran ini, Barat sesungguhnya telah berhasil dalam menciptakan karya seni berkualitas tinggi, namun yang menjadi masalah adalah isi atau kandungan yang disampaikannya. ${ }^{29}$

Secara umum, dari berbagai tema yang dibahas ini, bisa ditarik kesimpulan bahwa sebagian besar para peneliti di negara-negara Asia dan Islam, sepakat bahwa bangsa-bangsa Dunia Ketiga haruslah melepaskan diri dari sikap pasif dalam menghadapi globalisasi. ${ }^{30}$

Mereka haruslah berupaya secara aktif mengenalkan potensi-potensi yang tersembunyi di negara-negara Dunia Ketiga, terutama negara-negara Islam, kepada bangsa dan budaya-budaya lain. Bahkan arus globalisasi akan dengan mudah saja mendatangkan musibah kepada seni kita, karena ia sama seperti badai taufan yang mungkin mencabut akar budaya. Tetapi dari sudut pandang yang lain, globalisasi bisa memberikan kesempatan istimewa untuk bangsa-bangsa yang kaya dengan budaya. Seni kita akan tersebar ke luar batas negara dan memberikan pengaruh kepada dunia. Sejarah menyaksikan bahwa pada berbagai era kegemilangan, seni dari Iran, India, dan Italia berkembang sampai ke negara-negara yang jauh. Masalah inilah yang mungkin terjadi hari ini. Karena itu, bangsa Asia yang percaya

pada hal ia adlah musuh dan perampas bumi kita. Kebudayaan global menginginkan agar kita memberikan kepadanya pengakuan resmi bahwa semua yang telah rampasnya adalah miliknya dan bahwa ia punya wewenang untuk mengingatkan setiap Negara arab yang menolaknya. AlQaradhawi, Islam dan Globalisasi Dunia, (Jakarta Timur: Pustaka al-Kautsar: 2001), cet ke-1, h. 57

${ }^{28}$ A. Qodri Azizy, Melawan Globalisasi, (Yogyakarta: Pustaka Pelajar, 2004), h. 3

${ }^{29}$ A. Qodri Azizy, Melawan Globalisasi, h. 3

${ }^{30}$ Tapi menurut Qaradhawi, kita tidak akan mungkin mampu melawan arus globalisasi ekonomi manakala kita tidak sanggup menentang arus globalisasi kebudayaan yang begitu besar yang menghantam setiap penghalang. Kita akan mampu menentangnya hanya dengan iman, akhlak, dan syari;at kita. Qaradhawi, Islam dan Globalisasi Dunia, (Jakarta: Pustaka al-Kautsar: 2001), Cet ke-1, h. 63 
kepada kekuatan akar budaya mereka tidak perlu takut pada pengaruh asing. Kita harus berusaha untuk memahami bagaimana seni bisa menjadi tameng pertahanan budaya dan tradisi. ${ }^{31}$

\section{Globalisasi dan Tantangan Dunia Islam}

Pada era globalisasi ini kita menyaksikan terjadinya persaingan yang tidak seimbang antara apa yang dikelompokkan sebagai Barat dan Timur, atau Utara dan Selatan. Dari segi ilmu pengetahuan, teknologi dan pandangan hidup, dunia dibagi menjadi Barat dan Timur. Barat untuk negara-negara yang maju ilmu pengetahuan dan teknologinya serta punya pandangan hidup rasional dan sekuler, Timur sebaliknya.

Sedangkan dari segi ekonomi, dunia dibagi menjadi Utara dan Selatan. Utara untuk negara-negara yang maju ekonominya, sedangkan Selatan untuk negara-negara berkembang dan terbelakang. Letak geografis sama sekali tidak menjadi pertimbangan. Maroko yang terletak di Barat dimasukkan dalam kelompok Timur, sementara Jepang yang terletak di Timur dimasukkan dalam kelornpok Utara. Australia yang terletak di Selatan dimasukkan kelompok Utara. Seluruh negara-negara yang tergabung dalam Organisasi Konferensi Islam (OKI), termasuk Indonesia, masuk dalam kelompok negara-negara Timur dan Selatan.

Begitu juga dari segi budaya dan bermacam-macam ideologi, paham dan gaya hidup akan saling mempengaruhi dengan cepat, mengubah dengan cepat pula tatanan masyarakat. Sekali lagi, walaupun secara teoritis semua anggota masyarakat dunia saling mempengaruhi, karena kekuatan yang tidak seimbang, yang akan menguasai dan memaksakan pandangannya adalah negara-negara Barat. Sebagai akibat, maka kita dapat menyaksikan terjadinya perubahan-perubahan alam pikiran yang cenderung pragmatis, materialis, dan hedonis, serta menumbuhkan budaya inderawi (kebudayaan duniawi yang sekuler).

Penetrasi budaya dan multikulturalisme yang dibawa oleh globalisasi akan makin nyata dalam kehidupan bangsa. Mau tidak mau, suka tidak suka, setiap negara atau bangsa akan masuk dalam arus globalisasi. Yang

${ }^{31}$ Untuk lebih jelasnya silahkan baca Peper pengantar untuk seminar, Lumpuhnya Sistem Keadilan: Tantangan Penegakkan Hak-hak Azazi Manusia dan Peran Advokat Untuk Kepentingan Publik, yang di selenggarakan oeh Elsam Sawith Wach, HUMA, 3-5 Aug 2010, Jakarta. 
tidak dapat berenang akan tenggalam dalam pusaran arus yang sangat deras tersebut. Apalagi negara-negara Barat atau Utara menghendaki globalisasi tentu saja bukan tanpa kepentingan nasional masing-masing, baik ekonomi, budaya maupun ideologi atau paling kurang pandangan hidup.

Dunia Islam yang semuanya tanpa kecuali masuk Timur atau Selatan tentu saja tidak akan mampu menahan laju globalisasi itu, apalagi menghentikannya. Karena itu, globalisasi sudah merupakan realitas sejarah yang tidak dapat ditolak. Globalisasi adalah konsekuensi logis dari kemajuan teknologi komunikasi.

Lemahnya kualitas sumber daya manusia itu berakibat lemahnya penguasaan dan pengelolaan sumber daya alam, belum lagi mental korup para penguasa dan pengelola kekayaan alam. Selain itu berakibat tidak adanya persatuan umat Islam dunia dalam arti yang sebenarnya. Belum lagi pada dataran kepercayaan umat, banyaknya aliran teologi, mazhab fikih, organisasi massa, dan partai politik terkadang bisa menyebabkan kekuatan umat menjadi tidak berarti.

Disamping problem di atas yang tak kala pentingnya ialah peran media, sebagai suatu contoh ratio perbandingan masyarakat yang membaca Koran ternyata lebih rendah daripada menonton televise atau internet. ${ }^{32} \mathrm{Di}$ samping itu serbuan serbuan informasi dari berbagai media massa ternyata melebihi kapasitas ingatan manusia sehingga khalayak terbebani. Asumsi ini tidak berlebihan sebagaimana ditulis oleh Neuman, bahwa setiap hari televisi memperlihatkan 3.600 image permenit, radio rata menyiarkan kata-kata 100 kata permenit, dan internet menyajikan rata-rata 150.000 perhari. ${ }^{33}$

Pencitraan (image) telah menjadi mode bagi kalangan politisi dewasa ini, lihat dalam kampanye calon legislatif dan calon presiden telah memanfaatkan media massa dalam kampanye mereka. Shirly Biagy menyatakan bahwa dana kampanye banyak dihabiskan melalui media massa terutama televisi. Disengaja atau tidak arus informasi internasional yang dikuasai oleh kecanggihan teknologi komunikasi kini kelihatan didukung oleh konsep kebebasan informasi menurut pandangan barat. ${ }^{34}$ Media massa dengan kecanggihan teknologinya saat ini lebih memudahkan proses penyebaran

32 Russel, W, Neuman, (et.al), Common Knowledge, News an the Communication of Political (Chicago: Meaning, The University of Chicago Press, 1992), h. 90

${ }^{33}$ Burhan Bungin, M. Konstruksi Sosial Media Massa, (Jakata: Kencana, 2004), h. 48

${ }^{34}$ Muis, A. Komunikasi Islami, (Bandung: Remaja Karya, 2001), h. 19 
dakwah. Paul Lazarsfeld dan Robert K Merton juga melihat media dapat menghaluskan paksaan sehingga tampak sebagai bujukan. ${ }^{35}$

Sejalan dengan itu harus dipahami manfaat dan mudharat teknologi informasi dan komunikasi, serta secara sadar memanfaatkannya untuk mencapai tujuan kita, bukan tujuan-tujuan mereka (pembuat dan pencipta teknologi). Artinya kita sebagai pengguna informasi baik sebagai subjek atau pun objek jangan sampai terjebak dengan kepentingan-kepentingan yang tersembunyi dabalik kecanggihan media tersebut.

Disinilah titik perjuangan atau jihad di bidang dakwah oleh para da'i atau lembaga dakwah, dimana kalau dulu bangsa-bangsa berjuang menguasai wilayah atau berjuang untuk kemerdekaan wilayahnya, sekarang orang mulai berjuang dibidang baru yaitu informasi agar tidak dikendalikan oleh yang menguasai informasi. ${ }^{36}$

Dalam rangka membebaskan umat dari sifat-sifat kejahiliahan modern dengan pendekatan bil hikmah. Menurut Enjang yang mengutib dari pandangan Sayid Quthub bahwa dakwah dengan metode hikmah akan terwujud apabila memperhatikan tiga faktor. Pertama, keadaan dan situasi orang-orang yang didakwahi. Kedua, ada atau ukuran materi dakwah yang disampaikan agar mereka tidak merasa keberatan dengan beban materi tersebut. Ketiga, metode penyampaian materi dakwah dengan membuat variasi sedemikian rupa yang sesuai dengan kondisi pada saat itu. ${ }^{37}$

Seperti media internet yang akhir-akhir ini perkembangannya sangat fenomenal memiliki pengaruh langsung yang sangat kuat kepada pembacanya. Internet mampu menggerakkan prilaku massa sesuai dengan arah yang dikehendakinya. Kenyataanya massa tidak memiliki daya apa-apa, sehingga karena kehalustajamannya itu, Jalaluddian Rakhmat melukiskannya, ibarat seorang pasien yang tidak berdaya apa-apa setelah dimasuki sejenis serum melalui jarum kecil dalam tubuh. ${ }^{38}$

Fenomena tersebut dapat kita amati dengan terbentuknya keluarga-

${ }^{35}$ L. Rivers, Wiliam dan W. Jensen, Jay, Media Massa dan Masyarakat Modern, Terj, (Jakarta: Prenada Grup, 2008), h. 35

36 Ziauddin Sardar, Information and Muslim World: A Strategy for 21'st Century, 1988/ Tantangan Dunia Islam Abad 21, (Bnadung: Mizan. 1988)

${ }^{37}$ Enjang As, Dasar-dasar Ilmu Dakwah, Pendekatan Filosofis danPraktis, ( Bandung: Widya Padjadjaran, 2009), h 89

${ }^{38}$ Jalaluddin Rakmat, Psikologi Komunikasi, (Bandung: PT Remaja Rosdakarya, 1988), h. 88 
keluarga besar elektronik bersatu dalam jaringan sosial dan dalam jaringan kerja yang lebih besar. Jaringan-jaringan tersebut akan memberikan jasa pelayan sosial atau bisnis yang diperlukan melalui asosiasi-asosiasi. ${ }^{39}$

Jaringan sosial di dunia maya tersebut sangat berpotensial untuk dimanfaatkan sebagai sarana dakwah. Tentu saja kita tidak boleh melupakan dan mengabaikan tenaga-tenaga yang akan mengisi aktifitas dakwah di mesjid-mesjid dan majelis taklim..

\section{Penutup}

Sebagai penutup, perlu dipahami bahwa globalisasi telah menjadi lokomotif perubahan tata dunia dan akan menarik gerbong-gerbongnya yang berisi budaya, pemikiran maupun materi. Hal ini membawa konsekwensi yang besar terhadap pergeseran tata nilai dalam masyarakat, termasuk agama. Oleh karena itu, dakwah Islami diharapkan dapat menyaring dampak negatif tersebut.

\section{Pustaka Acuan}

Al-Qaradhawi, Yusuf, Islam dan Globalisasi Dunia, Jakarta: Pustaka AlKautsar: 2001, cet ke-1.

Agustian, Ari Ginanjar. ESQ; Emotional Spiritual Quetiont, Jakarta: Arga, 2002.

Ar-Rasyid, Ahmad Muhammad, Khittah Dakwah, Jakarta: Robbani Press, 2005.

Atiyah, Amaluddin, al-Waqi wa al-mitsâl fi al-fikri al-islami al-muasir, Beirut: Darr al-huda, 2002.

Azizy, A. Qodri, Melawan Globalisasi, Yogyakarta: Pustaka Pelajar, 2004.

Bachtiar, Wardi, Metodologi Penelitian Ilmu Dakwah, Jakarta: Logos Wacana Ilmu, 1997.

Bungin, M. Burhan, Konstruksi Sosial Media Massa, Jakata: Kencana, 2004.

Effendy, Onong Uchjana, Ilmu, Teori dan Filsafat Komunikasi, Bandung:

PT. Citra Aditya Bakti, 2000.

Enjang As, Dasar-dasar Ilmu Dakwah, Pendekatan Filosofis danPraktis,

${ }^{39}$ Alvin Toffler, The Third Wave, (Jakarta: Panca Simpati, 1973) 
Bandung: Widya Padjadjaran, 2009.

Halim, Abdul El-Muhammady, Dinamika Dakwah Suatu Perspektif dari Zaman Awal Islam hingga Kini, Kuala Lumpur: Budaya Ilmu, 1992. Muis, A. Komunikasi Islami, Bandung: Remaja Karya, 2001.

Mulyana, Dedy, Komunikasi Antar Budaya, Bandung: Roda Jaya, 2005.

Neuman, Russel, W, (et.al), Common Knowledge, News an the Communication of Political Chicago: Meaning, The University of Chicago Press, 1992. Peper pengantar untuk seminar, Lumpuhnya Sistem Keadilan: Tantangan Penegakkan Hak-hak Azazi Manusia dan Peran Advokat Untuk Kepentingan Publik, yang di selenggarakan oeh Elsam Sawith Wach, HUMA, 3-5 Aug 2010, Jakarta.

Rakmat, Jalaluddin, Psikologi Komunikasi, Bandung: PT Remaja Rosdakarya, 1988.

Sardar, Ziauddin, Information and Muslim World: A Strategy for 21'st Century, 1988/Tantangan Dunia Islam Abad 21, Bandung: Mizan. 1988.

Wahid, Fathul, e-Dakwah: Dakwah Melalui Internet, Yogyakarta: Gava Media,, 2004.

Wiliam. L. Rivers, dan W. Jensen, Jay, Media Massa dan Masyarakat Modern, Terj, Jakarta: Prenada Grup, 2008.

Toffler, Alvin, The Third Wave, Jakarta: Panca Simpati, 1973.

Yatim, Badri, Sejarah Peradaban Islam, Jakarta: Raja grafindo Persada, 2008. 